\title{
Effect of Drought Stress on the Growth and Development of Saffron (Crocus Sativus. L) in Eastern Morocco
}

\author{
Ibtissam Mzabri", Manal Legsayer, Fatimzahhra Aliyat, Mohammed Maldani, Nour Eddine \\ Kouddane, Azzouz Boukroute, lbtihal Bekkouch, and Abdelbasset Berrichi
}

Laboratory of Biology of Plants and Microorganisms, Faculty of Sciences, B.P. 717, Oujda 60000, Morocco

Received: January 19, 2017 / Accepted: March 4, 2017

\begin{abstract}
Saffron (Crocus sativus L.; Iridaceae) is the most expensive spice in the world. It has been cultivated in Morocco for centu-ries and has represented a traditional staple for culinary, medical and cosmetic uses. The present work is about the study of the effect of drought stress on Saffron's morpho-physiological and biochemical param-eters. An experiment has been carried out on a 4-year-old saffron plantation planted in an open field located in the experimental station of the Faculty of Sciences of Oujda. The experimental treatment included three water regimes (TO: Control receiving 100\% ETO, T1: moderate water deficit receiving $60 \%$ ETO, T2: pronounced water deficit re-ceiving only $40 \%$ ETO). The results show that the increase in drought stress levels has slightly influenced the different param-eters of saffron growth. At the foliar level, the effect of stress has resulted in a de-crease in the chlorophyll content, a slight decrease in the PSII quantum yield and a Proline content accumulation as soluble sugars and total phenols, which resulted in keeping the relative water content (RWC) and the Malondialdehyde (MAD) content at a level similar to that of the control. In gen-eral, the morphophysiological adaptation traits were observed even at severe level of water stress (40\% ETO) which resulted in an acceptable decrease in stigmas yield.
\end{abstract}

Keywords: Saffron, drought stress, growth, photosynthesis, performance, corm diameter.

*Corresponding author: btissammzabri@gmail.com

\section{Introduction}

By 2050, the demand for water is expected to increase by $55 \%$, not only under the pres-sure of a growing population, but also be-cause the continuous increased consumption. As for the agricultural sector, experts believe that the current levies are not sustainable (Ligtvoet et al., 2014). The problem is becoming more severe in the arid and semi-arid areas, which constitute about two-thirds of the Earth's surface (Benbrahim et al., 2004). The limited water resources in these areas are subject to competi-tion between agricultural and other uses, and the search for better adaptations of plants lacking water is thus becoming a serious issue.

Plants grown under drought condition have a lower Relative water content and leaf water potential. Obviously, exposure wheat and rice plants to a drought stress substantially decreased the leaf water potential, relative wa-ter content and transpiration rate (Siddique et al., 2001). Severe drought stress also de-creases the rate of photosynthesis (Kawamitsu et al., 2000). Plants survive under drought stress by using various morphological, bio-chemical and physiological responses. (Chaves and Oliveira, 2004). One of the most common stress tolerance strategies in plants is the accu-mulation of osmolytes including soluble sugars, proline, sugar alcohols (Serraj and Sinclair, 2002). Overall, they contribute toward osmot-ic adjustment, detoxification of reactive oxy-gen species and stabilization of membranes (Farooq et al., 2009).

Saffron, dried stigma of the Crocus sativus flower, is considered among the main terroir products of Morocco. In 2015, the saffron plantation in Morocco was conducted in a sur-face
ATLOS Publishing, LP
This is an Open Access article distributed under the terms of the Creative Commons Attribution License (http://creativecommons.org/licenses/by/3.0/), which permits unrestricted use, distribution, and reproduction in any medium, provided the original work is properly cited. 
area of around 1600 ha with an aver-age yield of 3.5t, making Morocco the fourth saffron producer in the world. According to the edaphic-climatic requirements, saffron is a rustic plant, and thanks to its morphology and physiology, it is able to withstand severe cli-matic conditions (Alizadeh et al., 2009). Pro-moting saffron cultivation in arid and semi-arid zones will enhance these areas, which are currently hard to cultivate due to the scarcity of water resources and will contribute to the support of low-input agriculture systems, to improve the incomes of small producers and to limit the rural exodus.

The present study aims to elucidate the in-fluence of the drought stress on the agro mor-phological and physiological behavior of saf-fron plants under the natural conditions in the semi-arid climate of eastern Morocco and un-der controlled hydric conditions.

\section{Materials and Methods}

\section{Experimental Site}

The experiment was conducted in an open field at the Experimental Research Station of the Faculty of Sciences of Oujda, located at $661 \mathrm{~m}$ altitude and $34^{\circ} 39$ '06-71" north and $01^{\circ}$ 53 '58-80” West (GPS Back Track Bush-nell).

\section{Plant Material}

The plant material used in this trial corre-sponds to saffron plants planted on 18/10/2011 in an open field. The corms used are from the region of Taliouine, the main ar-ea of saffron production in Morocco.

\section{Treatments Used}

To assess the effect of drought stress on the saffron crop, the plants were subjected to three different water regimes for a period of two years (2014-2015). These regimes correspond respectively to $100 \%, 60 \%$ and $40 \%$ ETO (reference evapotranspiration), taking into account the rainfall of Oujda. The water used for watering has an electrical conductivity of $0.7 \mathrm{mS} / \mathrm{cm}$.

\section{Experimental Design}

The adopted experimental design is ran-domized complete block, includes 3 blocks with a total of 45 saffron plants, the blocks indicate the repeats and sub blocks represent treatments.

\section{Measured Parameters}

The eco-physiological response of saffron to the hydric stress was evaluated on the morpho-logical, physiological and biochemical pa-rameters frequently used in the work concern-ing the response of plants to the various abiotic stresses including:

Stigma yield: the flowers were harvested ear-ly in the morning, then the stigmas are spread on flat receptacles in the shade for a few days, and the weight was obtained by weigh-ing the dry stigmas.
Number of leaves: counted each month for each plant Length of leaves $(\mathbf{c m})$ : growth in length of the aerial part (leaves) was evaluated every month with a scale in millimeters (mm) from the leaf base to the top.

Leaf area $\left(\mathrm{cm}^{2}\right)$ : in view of the morphology of the leaves of saffron, the leaf area is estimat-ed directly using the AUTOCAD 2010 soft-ware. The total leaf area is estimated by mul-tiplying the number of leaves by the leaf area unit.

Number and weight of corms: at the end of the cycle, plants have been dug up, corms rid of topsoil, cleaned and de-tunicates then the number and weight of corms have been de-termined.

Caliber of corms: calibre of corms was deter-mined by using a caliper. Three sizes are dis-tinguished: large caliber: $\varnothing>$ $2.5 \mathrm{~cm}$, medium caliber: $1.5 \mathrm{~cm}<\varnothing<2.5 \mathrm{~cm}$ and small caliber: $\varnothing<1.5 \mathrm{~cm}$.

Relative water content (RWC \%): relative water content of leafs was determined by the method described by Barrs, (1966). After-wards, the following formula was used to esti-mate the water content: TRE $(\%)=[($ PF-PS) $/$ PT-PS) $] * 100$, with TRF: relative water content, PT: weight in full turgor (g), PS: dry weight (g).

Leaf water potential $(\psi F)$ : This measure rep-resents the strength by which water is retained in the plant. The leaf water potential is meas-ured according to the Scholander method (Scholander et al., 1965).

Determination of chlorophyll pigments: Total chlorophyll is determined according to the method of Tran et al., (1995). Total chlo-rophyll concentration is determined by follow-ing formula: $[\mathrm{chl}(\mathrm{a}+\mathrm{b})]=(7.15 \times$ OD $663+18.71 \times$ OD 646) $\times \mathrm{V} / \mathrm{M}$ with: chl $(a+b)$ to-tal chlorophyll (mg.g-1FM), V: volume of total extract ( $\mathrm{ml}) \mathrm{M}$ : mass of fresh material ( $\mathrm{g}$ ) and OD: optical density. Quantum Efficiency measurement ( $\varphi$ PSII): Chlorophyll fluorescence is measured using the FMS Portable Fluor meter Model FMS (FMS 2 Pulse Modulated Chlorophyll Fluorescence Monitoring System, Hansatech, England). This device automatically records the $\Phi P S I I$, which displays the quantum efficiency of the PSII.

Dosage of proline: leaf proline content was determined according to the method of Monneveux and Nemmar (Monneveux et al., 1986). The content of proline was calculated with reference to a proline standard curve.

Dosage of soluble sugars: leaf soluble sugar was determined according to the method of Yemn and Willis (1954) reported by Sidari et al., (2008). The content of soluble sugars was calculated with reference to a glucose stand-ard curve.

Determination of membrane lipid perox-ides: malondialdehyde (MDA) is determined according to the method of Heath and Paker, (1968). The amount of MDA is calculated using a molar extinction coefficient of $155 \mathrm{nM}-1 . \mathrm{cm}-1$, according to the Beer-Lambert law: Ab-sorbance $=\mathrm{C} \times \mathrm{W} \times[\mathrm{C}](\mathrm{C}$ : molar extinction coefficient, W: width of the tank $(1 \mathrm{~cm})[C]$ : Concentration). Dosage of total phenol: extracting phenolic compounds was performed according to the method described by Ollivier et al., (2004).The results are expressed in microgram of caffeic acid / $g$ of saffron fresh material. With reference to caffeic acid standard curve. 


\section{Atatistical Analyzes}

The values of different parameters were expressed as the mean. SPSS statistical analy-sis software was used for analysis of variance, ANOVA and Duncan's multiple range tests were utilized to separate means in 0.05 confi-dence level. In order to examine the interrela-tions among a variables studied to identify the underlying structure of those variables, An ACP analysis was done using the XLSTAT software.

\section{Results and Discussion}

\section{Effect on Yield and its Parameters}

The field monitoring showed that drought stress influenced the flowering parameters. The first flowers were observed in the control fol-lowed by treatment $60 \%$ ETO. The number of flowers is inversely proportional to the intensity of stress. The highest yield was recorded in the control while treatment $40 \%$ showed the low-est yield (-29\%). This can be explained by the reduced number of flower buds in the first year of the stress that would depend on the importance of the stocks stored at the corms level during the vegetative phase. However, the decrease in yield observed between water treatments is not statistically significant, which indicates that saffron allows the production of an acceptable yield even under severe and prolonged water conditions (Table 1).

\section{Effects on the Aerial Part}

\section{Effect on the Morphological Parameters}

The obtained results show that the number of leaves, the leaf length, the leaf area are inversely proportional to the intensity of the stress when the lowest values were observed in the treatment $40 \%$ ETO (Table 2). These pa-rameters vary according to the months. The lowest values observed in April for all treat-ments. This period coincides with the end of the cycle. The reduction of the leaf area following the reduction of the cellular elongation is one of the plants' first reactions to water deficit. It contributes to the conservation of water re-sources, which allows the survival of the plant (Lebon et al., 2004) and is therefore consid-ered as a reaction or adaptation to the lack of water (Blum et al., 1996).

\section{Effect of the Plant's Hydric Parameters}

The hydric status of the leaves shows that the relative water content and the leaf water po-tential $-\Psi f$ - decreased in proportion to the intensity of the applied hydric stress. The most notice-

Table 1. Effect of different levels of drought stress on the stigma yield.

\begin{tabular}{llll}
\hline treatment & $100 \%$ of ETO & $60 \%$ of ETO & $40 \%$ of ETO \\
\hline $\begin{array}{l}\text { yield }(g) / \\
\text { treatment }\end{array}$ & $0,37^{a}$ & $0,34^{a}$ & $0,26^{a}$ \\
\hline
\end{tabular}

Table 2. Effect of different levels of drought stress on morphological parameters.

\begin{tabular}{|c|c|c|c|c|}
\hline Month & Treatment & $\begin{array}{c}\text { Leaf } \\
\text { number }\end{array}$ & $\begin{array}{l}\text { Leaf Length } \\
(\mathrm{cm})\end{array}$ & $\begin{array}{c}\text { Leaf Area } \\
\left(\mathbf{c m}^{2}\right)\end{array}$ \\
\hline & $100 \%$ of ETO & $174^{a}$ & $22^{a}$ & $525^{a}$ \\
\hline & $60 \%$ of ETO & $140^{b}$ & $21^{a}$ & $373^{b}$ \\
\hline \multirow[t]{3}{*}{ January } & $40 \%$ of ETO & $124^{c}$ & $19^{a}$ & $209^{c}$ \\
\hline & $100 \%$ of ETO & $231^{a}$ & $27^{a}$ & $1225^{a}$ \\
\hline & $60 \%$ of ETO & $170^{b}$ & $24^{a}$ & $658^{b}$ \\
\hline \multirow[t]{3}{*}{ February } & $40 \%$ of ETO & $136^{c}$ & $22^{a}$ & $420^{c}$ \\
\hline & $100 \%$ of ETO & $190^{a}$ & $28^{a}$ & $960^{a}$ \\
\hline & $60 \%$ of ETO & $117^{b}$ & $25^{a}$ & $412^{b}$ \\
\hline \multirow[t]{3}{*}{ March } & $40 \%$ of ETO & $102^{b}$ & $21^{a}$ & $295^{b}$ \\
\hline & $100 \%$ of ETO & $155^{a}$ & $26^{a}$ & $513^{a}$ \\
\hline & $60 \%$ of ETO & $110^{b}$ & $24^{a b}$ & $356^{b}$ \\
\hline April & $40 \%$ of ETO & 80 b & $20^{b}$ & $250^{c}$ \\
\hline \multirow[t]{3}{*}{ Average } & $100 \%$ of ETO & $188^{a}$ & $26^{a}$ & $805^{a}$ \\
\hline & $60 \%$ of ETO & $134^{b}$ & $23^{a}$ & $449^{b}$ \\
\hline & $40 \%$ of ETO & $110^{b}$ & $20^{a}$ & $294^{c}$ \\
\hline
\end{tabular}

Significant differences in same column are shown by different letters $(a, b, c)$; $\mathrm{p}<0.05$.

able action is observed in March and April. The average values shows that the RWC decreased from $74.4 \%$ in the control to $69 \%$ for the moderate treatment and to $65 \%$ for the severe treatment. However, there were no significant differences among treatments (Table 3).

The maintenance of a high $\psi \mathrm{F}$ in plants could be explained by a strategy of avoid-ance which seems linked, to a complex set of morphological characters (mass and volume of the roots, shape of the leaves, etc.) making it possible to maintain a sufficient tissue hydra-tion for normal metabolic function. The maintenance of a high water content in the leaves under water stress could be explained by a high efficiency of osmotic adjustment, which counteracts the decrease in water potential without any significant reduction in RWC (Hsiao et al., 1976).

\section{Effect on Biochemical Parameters}

\section{Effect on Chlorophyll Content and Photosynthetic Activity}

The results show that the total chlorophyll content and the quantum performance of the PSIl decreased respectively with increasing drought stress degree. Under severe stress conditions (40\% ETO), the total chlorophyll content and quantum performance of the PSII decreased by $39.75 \%$ and $9.3 \%$, respectively. The variation in PSII quantum performance is almost stable as a function of water stress (Table 4). These results are confirmed by Oukarroum (2007), who showed that there is no loss in the PSIl quantum performance in barley under stress. Ykhlef and Diekoun, (2000) suggest that the survival of plants while there is a lack of water is partly due to the maintenance of the photosynthetic capacity of leaves. However, the rate of reduction of chlorophyll content is statistically significant during the month of April only. This could be explained by a level of relative water content that is high enough, making it possible to mitigate the effects of the ap-plied hydric stress. 
Table 3. Effect of different levels of drought stress on water parameters.

\begin{tabular}{|c|c|c|c|}
\hline Month & Treatment & $\begin{array}{l}\text { Relative Water } \\
\text { Content }(\%)\end{array}$ & $\begin{array}{c}\text { Leaf Water } \\
\text { Potential (MPa) }\end{array}$ \\
\hline & $100 \%$ of ETO & $74^{a}$ & $-6.4^{a}$ \\
\hline & $60 \%$ of ETO & $70^{a}$ & $-7.8^{a}$ \\
\hline \multirow[t]{3}{*}{ January } & $40 \%$ of ETO & $74^{a}$ & $-9.7^{a}$ \\
\hline & $100 \%$ of ETO & $75^{a}$ & $-7.8^{a}$ \\
\hline & $60 \%$ of ETO & $74^{a}$ & $-7.3^{a}$ \\
\hline \multirow[t]{3}{*}{ February } & $40 \%$ of ETO & $68^{a}$ & $-9.2^{a}$ \\
\hline & $100 \%$ of ETO & $72^{a}$ & $-8.6^{b}$ \\
\hline & $60 \%$ of ETO & $70^{a}$ & $-10^{b}$ \\
\hline \multirow[t]{3}{*}{ March } & $40 \%$ of ETO & $65^{a}$ & $-13^{a}$ \\
\hline & $100 \%$ of ETO & $69^{a}$ & $*$ \\
\hline & $60 \%$ of ETO & $63^{a}$ & $*$ \\
\hline \multirow[t]{2}{*}{ April } & $40 \%$ of ETO & $61^{a b}$ & $*$ \\
\hline & $100 \%$ of ETO & $74^{a}$ & $-7.6^{b}$ \\
\hline \multirow[t]{2}{*}{ Average } & $60 \%$ of ETO & $69^{a}$ & $-8.3^{b}$ \\
\hline & $40 \%$ of ETO & $65^{a}$ & $-10.6^{a}$ \\
\hline
\end{tabular}

Table 4. Effect of different levels of salt stress on biochemical parameters.

\begin{tabular}{|c|c|c|c|c|c|c|c|}
\hline Month & Treatment & $\begin{array}{c}\text { Total } \\
\text { Chlorophyll } \\
\text { Content } \\
\text { (mg/g FM) }\end{array}$ & $\begin{array}{l}\text { Quantum } \\
\text { Yield of } \\
\text { PSII' }\end{array}$ & $\begin{array}{c}\text { Leaf Proline } \\
\text { Content } \\
(\mu \mathrm{g} / \mathrm{g} \text { FM) }\end{array}$ & $\begin{array}{l}\text { Leaf Soluble } \\
\text { Sugars Content } \\
(\mu \mathrm{g} / \mathrm{g} \text { FM) }\end{array}$ & $\begin{array}{c}\text { Malondialdehyde } \\
\text { Content } \\
\text { (nmol/g FM) }\end{array}$ & $\begin{array}{c}\text { Total Phenols } \\
\text { Content } \\
(\mu \mathrm{g} / \mathrm{g} \text { FM) }\end{array}$ \\
\hline & $100 \%$ of ETO & $0.87^{a}$ & $0.76^{a}$ & $207.9^{b}$ & $2990.4^{a}$ & $0.00104^{a}$ & $238.6^{b}$ \\
\hline & $60 \%$ of ETO & $0.79^{a}$ & $0.71^{a}$ & $474.8^{\mathrm{ab}}$ & $3867.5^{a}$ & $0.00102^{a}$ & $349.1^{a}$ \\
\hline \multirow[t]{3}{*}{ January } & $40 \%$ of ETO & $0.76^{a}$ & $0.73^{a}$ & $1064.9^{a}$ & $3918.3^{a}$ & $0.00104^{a}$ & $307.6^{a}$ \\
\hline & $100 \%$ of ETO & $1^{a}$ & $0.75^{a}$ & $224.7^{b}$ & $2709.3^{a}$ & $0.00104^{a}$ & $236.3^{b}$ \\
\hline & $60 \%$ of ETO & $0.96^{a}$ & $0.73^{a}$ & $462.5^{\mathrm{b}}$ & $4030.1^{a}$ & $0.00125^{a}$ & $361^{\mathrm{ab}}$ \\
\hline \multirow[t]{3}{*}{ February } & $40 \%$ of ETO & $0.79^{a}$ & $0.72^{a}$ & $1212.3^{a}$ & $4301^{b}$ & $0.00132^{a}$ & $474.3^{a}$ \\
\hline & $100 \%$ of ETO & $0.93^{a}$ & $0.76^{a}$ & $226.8^{b}$ & $2394.3^{a}$ & $0.00144^{a}$ & $409.1^{b}$ \\
\hline & $60 \%$ of ETO & $0.86^{a b}$ & $0.75^{a}$ & $294.2^{b}$ & $2689^{a}$ & $0.00149^{a}$ & $417.5^{b}$ \\
\hline \multirow[t]{3}{*}{ March } & $40 \%$ of ETO & $0.78^{b}$ & $0.70^{a}$ & $306.8^{a}$ & $2851.5^{a}$ & $0.00203^{a}$ & $560.1^{a}$ \\
\hline & $100 \%$ of ETO & $0.84^{a}$ & $0.75^{a}$ & $144.7^{b}$ & $870.5^{b}$ & $0.00187^{b}$ & $300.8^{b}$ \\
\hline & $60 \%$ of ETO & $0.73^{a}$ & $0.71^{\mathrm{ab}}$ & $216.3^{a b}$ & $940.1^{\mathrm{ab}}$ & $0.00202^{a b}$ & $370.7^{a b}$ \\
\hline \multirow[t]{2}{*}{ April } & $40 \%$ of ETO & $0.51^{\mathrm{b}}$ & $0.66^{b}$ & $250^{a}$ & $1070^{a}$ & $0.00268^{a}$ & $468.6^{a}$ \\
\hline & $100 \%$ of ETO & $0.91^{a}$ & $0.75^{a}$ & $201^{b}$ & $2241^{b}$ & $0.00134^{a}$ & $296.2^{b}$ \\
\hline \multirow[t]{2}{*}{ Average } & $60 \%$ of ETO & $0.83^{a}$ & $0.72^{a}$ & $361^{b}$ & $2881^{a b}$ & $0.00144^{a}$ & $374.5^{\mathrm{ab}}$ \\
\hline & $40 \%$ of ETO & $0.71^{a}$ & $0.70^{a}$ & $708^{a}$ & $3035^{a}$ & $0.00176^{a}$ & $452.6^{a}$ \\
\hline
\end{tabular}

Significant differences in same column are shown by different letters (a,b,c); $p<0.05$. 1 PSII: Photosystem II (or water-plastoquinone oxidoreductase). 
Table 5. Effect of different levels of drought stress on the underground part.

\begin{tabular}{lcccccc}
\hline Treatment & $\begin{array}{c}\text { Corms } \\
\text { Weight }\end{array}$ & $\begin{array}{c}\text { Corms } \\
\text { Number }\end{array}$ & \multicolumn{3}{c}{ Corms Diameter } \\
\cline { 3 - 6 } & & & Big Diameter & Medium Diameter & Small Diameter \\
\hline $100 \%$ of ETO & $412.4^{\mathrm{a}}$ & $108^{\mathrm{a}}$ & $27^{\mathrm{a}}$ & $50^{\mathrm{a}}$ & $23^{\mathrm{a}}$ \\
$60 \%$ of ETO & $359.3^{\mathrm{a}}$ & $93^{\mathrm{a}}$ & $11^{\mathrm{b}}$ & $44^{\mathrm{ab}}$ & $45^{\mathrm{b}}$ \\
$40 \%$ of ETO & $367.8^{\mathrm{a}}$ & $116^{\mathrm{a}}$ & $10^{\mathrm{b}}$ & $37^{\mathrm{b}}$ & $53^{\mathrm{b}}$
\end{tabular}

Significant differences in same column are shown by different letters $(a, b, c) ; p<0.05$.

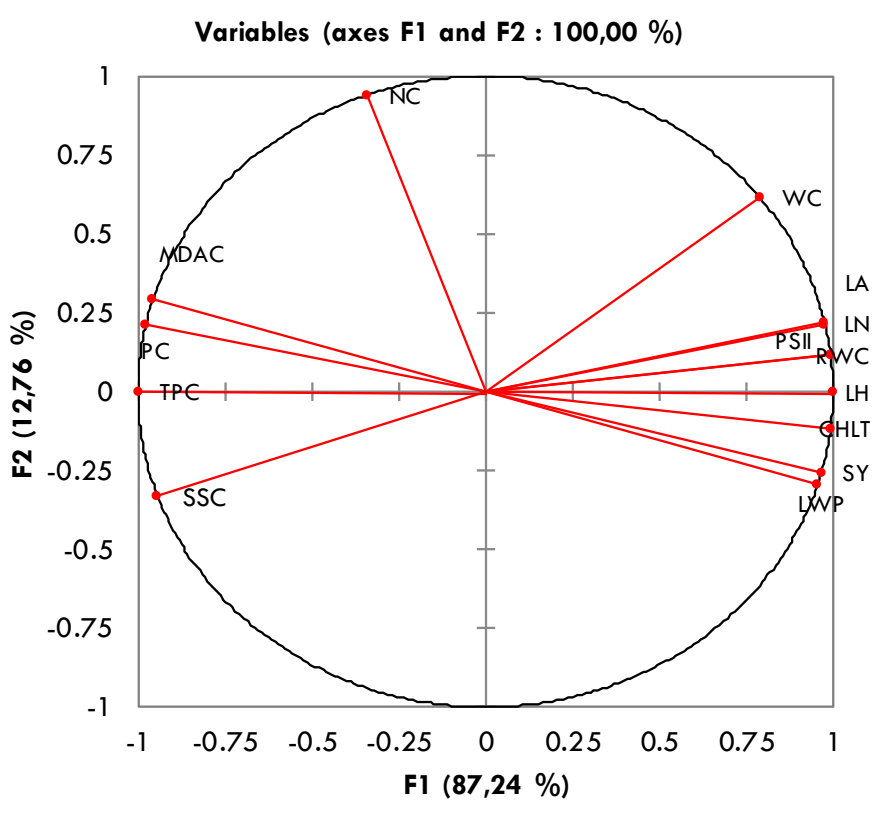

Figure 1. Representation of the studied characters in the plane (1-2). Principal Component Analysis. LA: Leaf area, LN: Leaf number, LH: Leaf height, SY: Stigma yield, RWC: Relative water content, LWP: Leaf water potential, CHLT: Total chlorophyll content, PSIl: Quantum Efficiency measurement, WC: Weight of corms, NC: Number of corms, PC: Proline content, SSC: Soluble sugars content, TPC: Total phenol content, MDAC: Malondialdehyde content.

\section{Effect on the Concentration of Proline and Foliar Soluble Sugars}

Plants were subjected to a water restriction produced more Proline and soluble sugars in their foliage (Table 4). This finding was in conformity with the result has been reported on Vigna unguiculata (Souza.,2004), alfalfa (Mefti et al., 2001) and wheat (Munns et al., 2006; Gaudillère et al., 1990). The accumulation of these solutes allows plants to support Lack of water, maintaining their relative leaf water content at a high level and preserving their cellular integrity. Furthermore, this accumula-tion could be the result of a high catabolism of the protein pool and in this case, it will not serve as a reliable diagnosis of resistance to drought.

However, the last two months before dor-mancy (March \& April) marked a drastic de-crease of these osmoregulators in all treat-ments, which resulted in a significant contrac-tion in the relative water content. This decrease could be explained by the cutback in photo-synthetic activity following the senescence of leaves, as it could be due to a translocation of the reserves (proteins, sugars ..) to the storage organs.

\section{Effect on Malondialdehyde Content and Antioxidant Activity}

The malondialdehyde (MDA) content was increased with intensity of stress. Overall, there were not significant differences between the treatments. In addition, the stressed plants ac-cumulated higher levels of total phenols, which could explain the maintenance of the MDA content at a comparable level of the control, and thus preserving membrane integrity (Table 4).

This result is confirmed by other authors such as Leinhos and Bergman; (1995) who have studied the involvement of polyphenols in the plant defense system against various types of stress. Also, Chakraborty and al., (2002) re-ported that phenol accumulation was im-portant in tea-tolerant cultivars.

\section{Effect on the Underground Part}

The results show that the highest weight (437 g) was recorded in the control versus $359 \mathrm{~g}(-12.77 \%)$ in the treatment $60 \%$ ETO and $367 \mathrm{~g}(-10.92 \%)$ in the treatment $40 \%$ ETO. Similarly, the percentage of diameter catego-ries varies according to the water regime ap-plied. Control showed a dominance of large and medium catégories, whereas the stressed plants marked a dominance of small diameter category which exceeded $50 \%$ in the sever treatment. However, Number of daughter corms was not significantly influenced by drought stress. The highest value was recorded in the 40\% ETO treatment with 116 corms (Table 5 ). The high rate of small diameter corms could be due to small quantity of reserves stored during vegetative phase. Several authors worldwide (Negbi et al 1989; De- maestro et al 1993; De Juan et al 2003; Koocheki et al., 2007; Çavușoğlu et al., 2009) have shown that large caliber en-hance precocity, flowering density and give large daughter corm for the next season.

\section{Principal Component Analysis}

The obtained results show that, with Axis 1 correlates all parameters studied which de-scribe the physiological and agronomic be-havior of the aerial part of saffron plant. On this axis, there is a very close correlation be-tween the vegetative growth parameters (LA, LN, LH), water parameters of the plant (RWC, LWP) and the chlorophyll content (CHLT, PSII). In addition, there is a negative correlation between the parameters involved in osmotic regulation (PC, SSC) and the other parameters studied. 
In other words the increase in the pro-duction of osmoregulators leads to a decrease in the growth parameters which is confirmed by the decrease of these parameters in the sever treatment. With axis 2, which represents the conversion efficiency of the biomass in re-placement corms, the number (NC) and the weight of the corms (WC) are correlated. On this axis, there is a relation of independence between these two parameters ( $\operatorname{Cos} \alpha=$ 0) (Figure 1).

\section{Conclusion}

Drought stress is one of the most important environmental stresses affecting agricultural productivity worldwide, where plants are ex-periencing a reduced growth and a reduced productivity. Our results show that the influence of the hydric stress on the morphological, phys-iological and biochemical parameters on saf-fron is not strongly marked at $60 \%$ ETO. Whereas at $40 \%$ of ETO the parameters stud-ied were more or less affected. The most no-ticeable effect was demonstrated by a decrease in the plant growth (decrease in num-ber, length and leaf area) as well as a de-crease in the diameter of daughter corms.

In general, morpho-physiological adapta-tion traits in water-deficient conditions have been externalized, resulting in an acceptable yield $(-29 \%)$ in the case of the severe treat-ments (40\% of ETO).

\section{References}

Ligtvoet, W., Hilder-ink, H., Bouwman, A., Puijenbroek, P., Lucas, P., \& Witmer, M. (2014). Towards a

world of cities in 2050. An outlook on water-related chal-lenges. Background report to the UN-Habitat

Global Report. Bilt-hoven: Netherlands Environmental As-sessment Agency

Alizadeh A, N Sayari, J Ahmadian, and A Mohamadian (2009) Study for zoning the most appropriate time of irrigation of saffron (Crocus sativus) in khorasan razavi, north and southern provinces. J Water Soil 23: 109-118.

Barrs HD (1968) Determination of water deficits in plant tissue. In: KOZLOWSKI, T.T. (Ed) Water defi-cits and plant growth. New York, Academic Press 1: 235-368.

Benbrahim KF, M Ismaili, SF Benbrahim, and A Tribak (2004) Problèmes de dégradation de l'environnement par la désertification et la défores-tation : impact du phénomène au Maroc. Sci Chang Planétaires / Sécheresse 15: 307-20.

Blum A (1996) Crop responses of drought and the interpretation of adaptation. J .Plant Growth Regul 20: 135-148.

Çavușoğlu A, E Erkel, and M Sülüșoğlu (2009) Saffron (Crocus sativus L.) Studies with Two Mother Corm Dimensions on Yield and Harvest Period Under Greenhouse Condition. Sustain Agric 3: 126129.

Chakraborty U, S Dutta, and BN Chakraborty (2002) Response of tea plants to water stress. Biol Plant 45: 557-562.

Chaves MM, and MM Oliveira (2004) Mechanisms un-derlying plant resilience to water deficits: prospects for water-saving agriculture. J Exp Bot 55: 2365-2384.

De Juan A, A Moya, S López, O Botella, H López, and R Mũnoz (2003) Influence of the corm size and the density of plantation in the yield and the quality of the production of corms of Crocus sativus L. Itea 99: 169-180.
De- maestro G, and C Ruta (1993) Relation between corm size and saffron flowering. Acta Horticultura 344: 51 2-517.

Farooq M, A Wahid, N Kobayashi, D Fujita, and SMA Basra (2009) Plant drought stress: effects, mecha-nisms and management. Agronomy for Sustainable Development. Agron Sustain Dev 29 (1): 185 212.

Gaudillère JP, and MO Barcelo (1990) Effets des fac-teurs hydriques et osmotiques sur la croissance des talles de blé. Agronomie 10 : 423- 432.

Heath R, and L Packer (1968) Photoperoxidation in isolated chloroplasts: I Kinetics and stoichiometry of fatty acid peroxidation. Arch Biochem Biophys 196: 385-395.

Hsiao TC, E Acevedo, E Fereres, and DW Henderson (1976) Stress metabolism: water stress, growth and osmotic adjustment. Philos Trans R. Soc Lond Ser B: Biol Sci 273 : 479-500.

Kawamitsu Y, T Driscoll, and JS Boyer (2000) Photosyn-thesis during desiccation in an Intertidal Alga and a Land Plant. Plant Cell Physiol $41(3)$ : 344-353.

Koocheki A, A Ganjeali, and F Abbassi (2007) The effect of duration of incubation and photoperiod on corm and shoot characteristics of saffron plant (Cro-cus sativus L.). Acta Horticulturae 739: 61-70.

Lebon G, E Duchene, O Brun, C Magne, and C Clem-ent (2004) Flower abscission and inflorescence car-bohydrates in sensitive and nonsensitive cultivars of grapevine. Sex Plant Reprod 17: 71-79.

Leinhos V, and H Bergmann (1995) Effect of amino alcohol application, rhizobacteria and mycorrhiza inoculation on the growth, the content of protein and phenolics and protein pattern of drought stressed lettuce (Lactuca sativa). J Appl Bot 69: 153-156.

Ligtvoet W, H Hilderink, A Bouwman, P Puijenbroek, P Lucas, and M Witmer (2014) Towards aworld of cit-ies in 2050. An outlook on water-related challeng-es. Background report to the UN-HabitatGlobal Report. Bilthoven: Netherlands Environmental As-sessment Agency. In press.

Mefti M, A Abdelguerfi, and A Chebouti (2001) Etude de la tolérance à la sécheresse chez quelques po-pulations de Medicago truncatula L. Gaertn .In : Qualité de la luzerne et des medics pour la produc-tion animale. Ciheam-lamz $45: 173-176$.

Monneveux $P$, and $M$ Nemmar (1986) Contribution à l'étude de la résistance à la sécheresse chez le blé tendre (Triticum aestivum L.) et chez le blé dur (Tri-ticum durum Desf.) : étude de l'accumulation de la proline au cours du cycle de développement. Agronomie 6: 583-590.

Munns R, AJ Richard, and A Lauchli (2006) Approaches to increasing the salt tolerance of wheat and other cereals. J Exp Bot 57: 10251043.

Negbi M, B Dagan, A Dror, and D Basker (1989) Growth, flowering, vegetative reproduction and dormancy in the saffron Crocus (C. sativus). Isr J Bot 38: 95113.

Ollivier D, E Boubault, C Pinatel, S Souillol, M Guérère, and J Artaud (2004) Analyse de la fraction phéno-liques des huiles d'olive vierges. A J Annales des falsifications, de l'expertise chimique et toxicologique 965: 169-196.

Oukarroum A, SE Madidi, G Schansker, and RJ Strasser (2007) Probing the responses of barley cultivars (Hordeum vulgare L.) by chlorophyll a fluorescence OLKJIP under drought stress and re-watering. Envi-ron Exp Bot 60: 438-446.

Scholander PF, HJ Hammel, A Bradstreet, and EA Hemmingsen (1965) Sap Pressure in Vascular Plants: Negative hydrostatic pressure can be measured in plants. Science 148: 339-346.

Serraj R, and TR Sinclair (2002) Osmolyte accumula-tion: can it really help increase crop yield under drought conditions? Plant Cell Environ 25: 333-341. 
Sidari M, C Santonoceto, U Anastasi, G Preiti, and A Muscolo (2008) Variations in Four Genotypes of Lentil under $\mathrm{NaCl}$-Salinity Stress. Am J Agri \& Biol 3 (1): 410-416.

Siddique MRB, A Hamid, and MS Islam (2001) Drought stress effects on water relations of wheat. Bot Bull Acad Sinica 41: 35-39.

Souza RP, EC Machado, JAB Silva, A Lagoa, and J Silveira (2004)
Photosynthetic gas exchange, chlo-rophyll fluorescence and some associated metabolic changes in cowpea (Vigna unguiculata) during wa-ter stress and recovery. Environ Exp Bot 51: 45-56.

Ykhlef N, A Djekoun, M Bensari, and D Vignes (2000) Déficit hydrique excès de lumière et activité photo-chimique chez le blé dur : analyse de la résistance des PSII. Sci Technol $10: 87$-92. 